\title{
GOMMUNIGATION
}

\section{MAJOR HUGH POLLARD, MI6, AND THE SPANISH GIVIL WAR}

\author{
GRAHAM D. MACKLIN \\ The National Archives, Kew
}

The recently released Special Operations Executive (SOE) personal file of Major Hugh Bertie Campbell Pollard (HS 9/1200/5) sheds new light on the man who helped fly General Franco from the Canary Islands to Morocco, leading ultimately to the overthrow of the democratically elected republican government and thirtysix years of brutal dictatorship. Contrary to the previous portrayal of Pollard, a genial, rough-and-ready gung-ho 'adventurer'1 who flew the future Caudillo to Morocco on a whim, the files reveal Pollard to have been an experienced British intelligence officer, talented linguist, and firearms expert with considerable firsthand experience of wars and revolutions in Mexico, Morocco, and Ireland, where he had served as a police adviser in Dublin Castle during the 'stormy days' of the Black and Tans in the early ig2os. Pollard, who listed his hobbies in Who's Who as 'hunting and shooting', was the sporting editor of Country Life and a member of Lord Leconfield's hunt. He was also a renowned and passionate firearms expert having written numerous books on the subject including the section on 'small arms' for the official war office textbook. His friend Douglas Jerrold, who himself later served in British intelligence, recalled that Pollard 'looked and behaved, like a German Crown Prince and had a habit of letting off revolvers in any office he happened to visit'. Once Jerrold plucked up the courage to ask Pollard if he had ever killed anybody. 'Never accidentally', he replied tartly. ${ }^{2}$

The outline of Pollard's involvement in Franco's flight from his exile as commander of the Las Palmas military garrison to Morocco where he took control of the African army is well known and needs only be briefly recounted here. On 9 July i936, Luis Bolín, London correspondent for $A B C$, the Spanish monarchist newspaper, followed the instructions of his Biarritz-based editor the Marqués de Luca Tena to lunch with Douglas Jerrold, editor of the decidedly right-wing Catholic periodical, The English Review, at Simpson's restaurant on the Strand. Their discussions centred upon finding a suitable crew for the De Havilland Dragon Rapide plane hired by Bolín, with funds from Spanish millionaire Juan March, from Olley Air Services at Croydon aerodrome, then London's main air

1 Paul Preston, Franco (London, I993), p. I36.

2 Douglas Jerrold, Georgian adventure (London, I937), p. 86. 
terminal. ${ }^{3}$ The plane's pilot, former Royal Air Force officer Captain William Henry Cecil Bebb, renowned for his skill and 'good nerves,' was originally led to believe that his cargo was a Riff leader being transported to Morocco to start a revolution, though he soon realized something more serious was afoot. In his autobiography Bolín recalled asking Jerrold to find 'two blondes and a trustworthy fellow' who, by posing as tourists, would act as 'cover' for the flight's real purpose. ${ }^{4}$ Having decided Pollard was the ideal man for the job, not least because of his fluency in Spanish, Jerrold rang him from the restaurant and asked him if he could be ready to fly to Africa the following day with two women. 'Depends on the girls', replied Pollard dryly. Whatever his hopes Pollard had to make do with his nineteen-year-old daughter, Diana, and her friend Dorothy Watson. Bolín and Jerrold arrived at his home in Middlehurst, Sussex, later that afternoon in order to finalize the details of the trip. ${ }^{5}$

Whether either Pollard or Jerrold alerted their contacts in British intelligence as to the nature of the plot in which they were involved is unclear. What is clear, however, was that the Foreign Office was aware that something was afoot. Although Captain Bebb flew Franco to Morocco on I8 July it was not until the 23rd that the British consul in Tenerife reported to his superiors the news that Franco had 'commandeered' a British registered aeroplane hired by Pollard. He had enough gumption, however, to indicate to his superiors his suspicion that 'possibly there was some pre-arrangement'. ${ }^{6}$ This was an understatement. As Bebb later remembered, whilst waiting for Franco at the Las Palmas garrison, the British consul himself arrived, 'and passed very favourable comments on the mission I was about to take part in. ${ }^{, 7}$

Having been successfully flown to Morocco a grateful Franco later awarded Pollard (and his fellow passengers) the Knights Cross of the Imperial Order of the Yoke and the Arrows, a Falangist decoration, in recognition of the role they played in his victory. His exploits also earned Pollard the appellation the 'Spanish pimpernel' from the American Life magazine. ${ }^{8}$ But Pollard's support did not end there. Throughout the Spanish Civil War he offered unqualified apologies for atrocities committed by Franco's military insurgents. When the Nazi Condor Legion levelled the symbolic Basque town of Guernica, an event since immortalized by Picasso, Pollard wrote an indignant letter to The Times from the comfort of his Sussex home asserting that Guernica, which he alleged was hub of the republic's small arms manufacture, was a 'perfectly legitimate target' particularly since it supplied arms to 'terrorists' in the British empire. The Basques, or at least those who supported the democratic republic 'are simply reaping what they have sown', scolded an unsympathetic Pollard. ${ }^{9}$

${ }^{3}$ March was also believed to have provided a subsidy to the British Union of Fascists led by Sir Oswald Mosley, see the National Archives (NA): KV 2/880.

${ }^{4}$ Luis Bolín, Spain: the vital years (London, I967), p. I7.

${ }^{5}$ Jerrold, Georgian adventure, pp. 369-74; Bolín, Spain, pp. I6-23.

6 H. Patterson, British Consulate, to Foreign Office, 23 July I936 in NA: FO 371/20525.

${ }^{7}$ Guardian, 25 June ig66. $\quad{ }^{8}$ Life Magazine, i8 Jan. r938. $\quad{ }^{9}$ Times, 3 May 1937. 
Such an attitude is hardly surprising; Pollard was a staunch Roman Catholic who regarded it as 'the duty of a good Catholic to help fellow Catholics in trouble'. He was also a visceral anti-Communist who believed, as he put it so eloquently in an interview with The Guardian in June Ig66 the month before his death, that Communists 'are better put down than anything'. ${ }^{\mathbf{1 0}}$ Although he feigned a 'gentleman's distaste' for politics and claimed never to have entertained a serious political idea in his life, Pollard was vice-chairman of his local Conservative association, describing his precise political stance as 'extreme right'. ${ }^{11}$ Right up until his death this included a strident sympathy for fascism and Nazism, though he preferred the Fascists who marched with Mussolini rather than the 'third-raters' that he believed were attracted to Hitler's standard. ${ }^{\mathbf{1 2}}$ Indeed, such were his pro-Nazi sympathies that Pollard narrowly escaped arrest when the British government ordered the mass internment of British fascists in June I940. In December I939 West Sussex police raided the Kent flat of Mrs Dacre-Fox, an 'active and industrious' fascist whom $\mathrm{MI}_{5}$ suspected of being a conduit of funds to Sir Oswald Mosley's British Union of Fascists (BUF) from Nazi Germany. During the search of her premises they discovered Pollard's name, and that of his daughter, in her address book. ${ }^{13}$ Armed with this evidence, such as it was, of a connection between Pollard and the BUF, $\mathrm{MI}_{5}$ were poised to request Pollard's arrest were it not for one crucial fact: Pollard was a member of their sister security agency, the Secret Intelligence Service (SIS), more commonly known as MI6. His Who's Who entry innocently indicates that during this period Pollard was employed on the War Office General Staff List, however. Upon learning that Pollard was an SIS agent $\mathrm{MI}_{5}$ ordered their regional liaison officer in Kent to 'lay off' Pollard. ${ }^{14}$

Indeed, despite full knowledge of these political sympathies MI6 had appointed Pollard head of its semi-autonomous 'Section D' in Madrid on 3I January I940. Section D was officially a sub-division of MI6 with a remit to engage in clandestine sabotage across Europe: in office parlance ' $D$ ' stood for 'Destruction. ${ }^{, 15}$ During May I940 Section D had what is described in the Special Operations Executive (SOE) in-house history as, 'one small flirtation' with the idea of backing the monarchist (not republican) opposition in Spain as part of the British government's overarching strategy to keep the country out of the war. The plan was soon abandoned, however, once it was realized that it had absolutely no chance of success. ${ }^{\mathbf{1 6}}$ It was Pollard, operating under the codename 'Don,' who was the MI6 officer at the forefront of this initiative, an initiative planned incidentally in conjunction with Sir Percy Loraine, the British ambassador to

${ }^{10}$ Guardian, 25 June i966. $\quad 11$ Note of interview, 23 Feb. I940, in NA: HS 9/I200/5.

12 Guardian, 25 June i966.

${ }^{13}$ Captain C. Grassby to Mrs Archer, I7 June I940, in NA: HS 9/I200/5.

14 [Illegible signature] to Lieutenant-Colonel Valentine Vivian, 23June I940, in NA: HS 9/1200/5.

15 Nigel West, Secret war: the story of SOE Britain's wartime sabotage organisation (London, I992), p. Io.

16 William Mackenzie, The secret history of SOE: the Special Operations Executive, 1940-1945 (London, 2000), p. $3^{2}$. 
Rome and Captain Alan Hillgarth, the British naval attaché in Madrid who, working closely with MI6, later organized the covert activities of the SOE in Spain whilst simultaneously serving as an unofficial intelligence adviser to the prime minister Winston Churchill. ${ }^{17}$ Hillgarth had also been an indispensable aide to the new British ambassador Sir Samuel Hoare, himself an experienced intelligence officer who had been the head of the MI6 station in Russia until I9I7. Hoare arrived to take over a Madrid embassy mired in defeatist opinion. On the day of his arrival Hillgarth counselled Hoare that: 'as it is Spain with whom we have to deal and the Spanish viewpoint is very much influenced by German and Italian propaganda, our belief in ourselves, which must betray itself in our words is of supreme importance'. ${ }^{18}$

Indulging themselves in a bizarre flight of fantasy Pollard's superiors seemed to have seriously entertained the notion of allowing him to approach his 'friend' General Franco and persuade him not only to accept the restoration of King Alfonso XIII to the throne, but to 'welcome' it. The net effect of this move, hoped Section D, would be to remove German and Italian influence from Franco's regime. The basic flaw in this plan, which senior Section D officers appear to have completely failed to appreciate, was that, not only was Franco more than comfortable with this influence, he actively courted it. Further proof of the unrealistic premise of this plan was signified by the involvement of Pollard himself whose participation, noted the anonymous author of a memo found in Pollard's file, 'scared me a great deal'. Such fears were entirely justified. Not only was Pollard considered out-of-touch by other senior Section D officers, but he was renowned as a 'dyed-in-the-wool' Franco supporter, and thus unlikely do anything to undermine the position of a man he so greatly admired. ${ }^{19}$

More importantly his superiors considered that whilst there were 'certain jobs' at which Pollard could 'do well' these skills were overshadowed by his reputation for being at best 'most indiscreet' and, when combined with money and drink, 'definitely unreliable.' His further involvement in the plan was therefore deemed 'fatal'. Such a dismal view of his character no doubt presaged Pollard's fall from grace. Before the year was out the question of his return and dismissal was tabled as a matter for 'urgent consideration. ${ }^{20}$ The same month Section D dispensed with Pollard's services, Winston Churchill ordered the formation of the Special Operations Executive (SOE), a clandestine organization that would 'set Europe ablaze' through covert action. Section D officially disbanded on 2 I October I940 and was re-titled $\mathrm{SO}_{2}$, which was subsequently absorbed into SOE. ${ }^{21}$ Pollard died in March I966 aged seventy-eight, an unrepentant supporter of the brutal Francoist regime, which he had played a crucial part in helping to install.

${ }^{17}$ David Stafford, Churchill and the secret service (London, I997), p. 209.

18 J. A. Cross, Sir Samuel Hoare: a political biography (London, 1977), p. 33I.

19 Memo re meetings with D on 4,5 , and 7 May 1940 in NA: HS 6/942.

${ }^{20}$ Colonel W. F. Jeffries to [no signature], I2 July I940 in NA: HS 9/I200/5.

${ }^{21} \mathrm{D} / \mathrm{A}$ to all officers, secretaries, subsections and stations, 2I October I940 in TNA: HS 8/334. I would like to thank Chris Murphy for bringing this reference to my attention. 